\title{
Islamic Family Law in Europe? From Dichotomies to Discourse Or: Beyond Cultural and Religious Identity in Family Law
}

\author{
Journal Article \\ Author(s): \\ Büchler, Andrea \\ Publication date: \\ 2012 \\ Permanent link: \\ https://doi.org/10.3929/ethz-b-000062379 \\ Rights / license: \\ In Copyright - Non-Commercial Use Permitted \\ Originally published in: \\ International Journal of Law in Context 8(Special Issue 02), https://doi.org/10.1017/S1744552312000043
}




\title{
Islamic family law in Europe? From dichotomies to discourse - or: beyond cultural and religious identity in family law
}

\author{
Andrea Büchler \\ University of Zurich
}

\begin{abstract}
In a number of European countries there are fears that foreign, particularly Islamic, family law is becoming entrenched. All parties to this discussion see themselves as under threat. Migrant populations claim their right to cultural identity, while their host countries' domestic populations see a risk to social cohesion. Family law brings the underlying tensions into sharp focus. Cultural and religious identity and family law are interrelated in a number of ways and raise various complex issues. European legal systems have taken various approaches to meeting these challenges, many of which have been apologetic, and few of which have been informed by theory. I propose to examine this complexity and indicate areas in which conflicts may arise by analysing a family-law case involving migrants living transnationally. I will include questions of international private law, comments on the various degrees of consideration accorded to cultural identity within substantive family law, and remarks on models of legal pluralism and the dangers that go along with them. I will conclude with an evaluation of approaches which are process-based rather than institution-based.
\end{abstract}

\section{Introduction}

In a number of European countries there are fears that Islamic family law is becoming entrenched. All parties to this discussion see themselves as under threat. Migrant populations are afraid of losing their cultural identity, while their host countries' domestic populations see a risk to social cohesion.

Family law brings these underlying tensions into sharp focus. There are two main reasons for this. First, family law is widely seen as the branch of law upon which traditions, religions and cultural values have impinged the most (Krause, 2006, p. I099). The family is acknowledged as constituting one of the most private spheres, yet there is hardly any other area of life which is confronted so forcefully by legal and societal expectations. It is this confrontation which gives rise to intense public debate about the role of the sexes, personal autonomy and the opportunities and threats presented by cultural diversity in Europe. In the Islamic context, family law is crucial to the legal canon (Poulter, I990, pp. I47-48). It is the branch of the law with the greatest density of regulation emanating from the highest-ranking sources. Moreover, although during the nineteenth century large parts of Islamic law were replaced by codifications based on the continental European model, most countries with a predominantly Islamic population have maintained a sharia-based family law to this day, even if, of course, each Islamic country has forged classical Islamic law in a different way (Pearl and Menski, I998, pp. I9-22). Sharia-based family law is therefore a symbol of collective identity and at the core of what it means to be a Muslim. In Europe, however, for many Islam is, as it were, the symbol of cataclysm, the quintessence of everything which threatens modernity. 
Second, Europe's current modernity has not come without a struggle. Nowhere is this more evident than in the field of family law. Divorce was first legalised in Spain in I982, and until I988 the Swiss Civil Code stated that the husband was the head of the family, that it was the wife's duty to run the household and that she was entitled to only one-third of any increase in the couple's joint wealth. Those rights which have been achieved remain fragile. It is certainly true that confrontation with all that is foreign tends to initiate a process of self affirmation, but in reviewing these issues, we should not forget recent European family-law history.

Cultural diversity and family law thus are interrelated in a number of ways and raise various complex issues. I propose to examine this complexity and indicate areas in which conflicts may arise. First, I will deal with international private law in European countries. What follows will include comments on the various degrees of consideration accorded to cultural identity within substantive family law, and some remarks on models of legal pluralism and the dangers that go along with them. I will conclude with an evaluation of various approaches which are processbased rather than institution-based.

\section{Cultural diversity in the context of family law}

Let me begin by highlighting the main issues.

\section{Some reflections on the semantics of cultural identities}

The semantics of cultural diversity incorporate the concept of otherness in a number of ways. Differentiation is a prerequisite for inclusion, however. What is this cultural identity which has the ability to distinguish between the self and all that is 'other'? On the one hand, cultural identity is an expressive, non-rational emanation of the personal. On the other hand, it is a construct invoked to recreate itself continuously in the social context. We often experience a more or less overtly stated binary logic, based on purported attributes of 'us' and 'them'. These attributes exert substantial influence throughout society, giving rise to concepts of social groups which are entrenched in collective memories such as 'Islam' or 'the Muslims'. The focus on difference sometimes results from the idea that there are a variety of entities, distinct from each other, self-contained, possessed of logics of their own and with the power to induce uniformity within themselves. Some legal discourse appears to suggest that this idea of culture is congruent with national identity. This is, of course, something of an oversimplification. Culture is not ontologically evident nor is it an anthropological constant. Globalisation has been a key factor in reshaping identity-determining areas. Transnational areas allow contradictory identities to evolve which are not only multi-pillared, but also universal, hybrid, multilingual and ubiquitous. However, on a subnational level, we also observe the formation of identity patterns whose intent is defensive, and which regularly have recourse to primordial categories such as ethnic origin and religious affiliation. Globalisation has thus produced two contrasting and parallel outcomes. It has not only made society more pluralistic, it has also made social groups more ethnic.

Religion is indeed experiencing something of a renaissance in cultural diversity discourse and is becoming an increasingly important form of self-identification. Indeed, emigration often raises people's consciousness of their religious affiliations, as a symbolic means of reinforcing their own identity (Van der Veer, I994, p. II9). Religion offers diaspora communities both a meaningful framework and a contact structure on which they can depend during times of crisis. There can be no doubt that European societies now have multifarious religious strands running through them.

\section{Is there a right to cultural identity in the context of family law?}

From its beginnings, Islam has been more interested in law than in theology, the more so as law is central to its message. Moreover, Islamic family law has a direct bearing on Muslim men and 
women living in Europe, especially since family life and religious conviction are closely linked. The question of whether there is a right to cultural identity in a family-law context is one which Europe is predisposed to take seriously, since there are essential human rights aspects to cultural and religious identity, and these aspects have a sound normative foundation. The right to cultural and religious identity has a firm basis in international law, as evidenced by the European Convention on Human Rights (ECHR), Article 8, and the UN Convention on the Rights of the Child, Articles 29 and 30. Of course, since human rights are regarded as universal, cultural considerations cannot impinge on them. However, in their emancipative focus human rights endow all individuals with equal rights to self-determination, and pave the way for differing modes of living to develop and hold their own. It is here that major questions arise. Should the pluralised society which migration has brought in its wake also result in legal pluralisation? How can homogeneity in family law be reconciled with cultural identity? What relevance do Islamic legal norms, expectations and practices have in the context of family law in Europe? Do European family-law codes have the openness to incorporate cultural diversity?

\section{Pluralisation of family forms and the opening up of family law}

Family forms in European countries have been subject to rapid change for decades and have become pluralised. The number of divorces is increasing, birth rates are falling, growing numbers of couples cohabit outside wedlock, while patchwork families are on the increase (Fux, 2002, pp. 363-64; Kaufmann, 2002, pp. 4I9, 423). A contradictory mixture of traditional longings and new expectations has brought forth a multiplicity of new ways of life. The same applies to family values. While the Christian idea of marriage as an institution is integral to collective memory, ontological examination shows that its key constitutive elements - enduring for a lifetime, monogamous and between members of opposite sexes - have little normative effect. The idea that there is a coherent, shared body of common Western family values is a fiction (Bainham, I995, pp. 237-38). Migration from Islamic countries and the renewed emphasis this has placed on traditional family structures and values has only added to this pluralisation.

To some extent, evolving European family law has adapted to this phenomenon. As differences within society have proliferated, so the meaning of family law has diminished: today, public interest is scarcely able to justify legal restrictions on the act of marriage, rules governing the internal structure of the marriage relationship or the sanctioning of its termination. The process of the state's withdrawal from the family area of life, however, has not been consistently thought through by any means.

\section{Real and virtual areas of law - the scope and limitations of conflict of laws rules}

Conflict of laws rules offer one way into investigating the relationship between cultural diversity and family law in Europe (Foblets, 2000). While not directed specifically to cultural diversity issues, these rules govern which law is applicable in family disputes involving foreign nationals. They are complex and they often present jurisprudence with exacting technical challenges. A limited number of critical observations will have to suffice here.

\section{Nationality-based jurisdiction and its erosion}

In many European countries - Germany, France and Spain being prominent examples - the choice of law which applies to many family issues continues to be determined by the nationality of the persons concerned (lex patriae). The idea appears to be that people have organised their lives based on one particular legal system and that their affinity to that system should be protected, even if the focus 
of their vital interests has shifted. Determining applicable jurisdiction on the basis of a person's nationality is meant to pay heed to a person's right to cultural identity. Thus, Lebanese divorce law applies to the divorce of a Lebanese couple living in Germany, while a Syrian couple wishing to marry in France is required to adhere to the prerequisites for marriage (for example, relating to capacity) laid down in Syrian law.

Making nationality the determining factor in international family law is in my view at odds with our times. It is difficult to justify the very premise on which it rests - namely that there is a close cultural affinity between the individual and the nation from which he or she derives nationality.

First, people's legal convictions can be greatly at odds with their legal circumstances, as is evidenced by marriages performed by imams in Turkey. Or one may consider the paradoxical case of the Iranian woman who fled from Iran to Europe after the Islamic revolution in order to get away from Iran's theocratic state and its Islamic law, only to find, decades later, that her national identity resulted in her divorce proceedings being subjected to that very same Islamic law.

Second, if international private law in European countries dictates that Muslim residents be judged according to the law of their foreign nationality, they will then not be permitted to benefit from the possibly more favourable provisions of the European codes. This can be particularly disadvantageous to Muslim women.

Third, a major objection to applying law based on an individual's nationality is that it does not pay adequate heed to those who are in the process of integrating in the country to which they have emigrated, but who have not yet acquired its nationality. Indeed, several European countries ask foreigners to meet the most stringent requirements for citizenship. The life of immigrants is often one of continuing transition. Cultural identification based solely on nationality can often overshadow the dialogue and dialectic of an individual's relationship to that which is other, masking the contradictions and simultaneity of the different elements in their cultural conditioning.

The dominance of nationality-based choice of law in European international private law hails from the era of the 'guest workers', when it was assumed that the immigrants brought in to rebuild Europe would eventually leave their host countries again, so that their 'distinctness' should be maintained. The Muslim presence we have had in Europe for the last forty years is different, however. They are here to stay (Nachmani, 2009, pp. 15-23).

Finally, it is not only because courts are not properly trained for such tasks that the application of foreign, religious law in Europe has proven to entail difficulties, but also because this practice effectively applies law outside its usual context, thus implying that the law is an idiopathic manifestation, and that jurisdiction is simple to perform and infallibly leads to a given result. It ignores that the law is in fact able to develop its content, its meaning and its effect only in a given cultural context, and that these are therefore susceptible of transformation.

The concept of applying law based on nationality is currently being eroded in a number of ways partly as a result of reform of the international private law of various countries, partly as a result of international treaties, and partly as result of attempts to harmonise European conflicts of laws. Furthermore, many jurisdictions introduced the practice of according spouses the choice of applicable law in certain matters (Foblets, 2000).

\section{Applicable law based on domicile}

In Switzerland and England domicile is the preponderant factor determining applicable law. Domicile implies that a person has settled in a country with the intention of remaining there permanently or indefinitely. As a result, Islamic law is applied far less frequently in Switzerland and England than it is in Germany, France or Spain.

Applying law on the basis of an individual's place of domicile does not ensure that their cultural identity is safeguarded. One problem arising from linking applicable law to a person's centre of vital interests is that the legal conditions prevailing in different jurisdictions are not attuned to each other. 
Thus, legal relationships established in Europe might not be recognised in the country of origin of the parties concerned. Nevertheless, the concept of determining applicable law on the basis of the parties' domicile is certainly a viable starting point for any discussion about the accommodation of cultural diversity. Only when the parties' lives exhibit genuinely transnational attributes is the application of the legal norms of other countries justified.

\section{Ordre public and self affirmation: alien tradition and own morality}

Ordre public (or public order) is a key element in international private law. Indeed, it is often the concept of ordre public which limits the applicability of Islamic law and marks the limits set on the recognition of legal decisions handed down in other countries. For example, can a marriage concluded between minors in an Arab country be recognised as valid in England or France? Or can a man who has repudiated his wife in his country of origin enter into a new marriage in Germany?

It is not the legal systems of other countries themselves which are being measured against the cardinal principles of our law canons. Rather, it is the result of applying those other countries' legal systems or of recognising their legal decisions that is being put to the test. If such outcomes contravene fundamental principles of our system of laws and values, then the law will not be applied and the legal decision will not be recognised. From a comparative perspective, it is perfectly possible for these boundaries to be drawn in different ways. Some boundaries, such as those protecting human rights, ${ }^{\mathrm{I}}$ are more compelling than others, such as those protecting familylaw dogma, ${ }^{2}$ and public order boundaries are particularly difficult when they are applied simply to justify the primacy of a country's own legal rules. This can be seen in the argument that talaq, the unilateral pronouncement of divorce by the husband, is too permissive, because it can be uttered extra-judicially, against which the wife has no right of recourse, at any time and even without notice of the talaq (Pearl and Menski, I998, pp. 280-86). It is of course true that divorce by talaq spectacularly violates a woman's human right to the due process of law. On the other hand, a woman who agrees with the talaq should then be entitled to dispense with the necessity of instituting new divorce proceedings herself. 3 And German courts may even apply foreign talaqlaw where there are valid grounds for divorce also under German law (Rohe, 2004, pp. 28-29). The key point is that it is only the result of the application of foreign law, not the foreign law itself, which may be assessed against the host country's system of values. Besides, European countries now permit unilateral divorces after ever-shorter periods of separation. Indeed, in Spain no period of separation at all is now required prior to a unilateral divorce. ${ }^{4}$ This is not very far from the Islamic concept of repudiation.

For all of these reasons, recourse to an ordre public rationale should be restrained by returning to values which transcend all societies, values enshrined in the fundamental human rights embodied in international law. The same conclusion could also be reached about determining the applicable family law on the basis of an individual's nationality. It is an approach based on exclusion. It is an approach which anticipates a difference, which it then re-emphasises with every decision. By the way it links people to legal systems it is thus a performative act, engaging in the binary logic of the self and the 'other'. Indeed, while legal pluralism is embedded in international private law, conflict of laws rules in international private law remain structurally unable to protect cultural

I Such as the prohibition of child and forced marriage.

2 Such as the prohibition of polygamy.

3 Germany and Switzerland, for example, recognise individual talaqs pronounced abroad as legally binding.

4 Art. 8I(2) and art. 82, Spanish Civil Code. 
identity. When Muslims assert a foreign cultural imprint but are nationals of a European country, conflict of laws is not even applicable.

\section{Accommodation of cultural and religious identity in substantive family law}

If international private law cannot accommodate cultural diversity in family law, we must then ask whether substantive family law is able to do so. The normative integration of diverse, culturally connotated perceptions of law can be examined on several different levels.

First, the codes of several countries include norms which require the authorities to pay due heed to religion, ethnic origin, cultural background and language, examples being the Children Act I989 in England5 and the code de procédure civil in France. ${ }^{6}$ However, such commitments to cultural diversity merely lend concrete expression to principles which are generally applicable in any case. These norms do nevertheless have considerable significance, not only because of their programmatic content, but also because they require that actions and decisions be justified, and such justification implies reflection on and disclosure of the decision parameters used and the cultural imperatives applied by those determining the case.

Second, the interpretation of general clauses, open normative terms and the balance of interests all offer potential to take different perceptions of family law and cultural expectations into consideration. For example, as a prerequisite to granting visiting rights to third parties, Swiss family law requires that an assessment be made as to whether 'extraordinary circumstances' exist.7 This assessment should be made with due regard to the cultural significance of family ties between relatives. To take another example, an assessment as to whether the wife has been forced into marriage, which would give grounds for a case for nullity, ${ }^{8}$ can be made only with reference to practices within a culture. Of course, this does not mean that forced marriages are justifiable on the grounds of cultural considerations, but merely that the conduct of those concerned can be understood and their intentions assessed only if the cultural context is known and its implications appreciated.

The greatest potential for consideration of a variety of value systems undoubtedly arises when the maxim of the child's best interests is applied. This maxim is firmly rooted in international law. 9 When parents inflict serious harm on their children an intervention undertaken by the state is justified, whilst trying to avoid aggravating tensions that can result in an irreparable break of the child with its family. However, to implement child-protection norms and practices which are both aware of, and sensitive to, cultural considerations is a difficult undertaking. There are two main reasons for this. On the one hand, cultural and religious considerations are played out in the tripolar arena of the child's needs, the autonomy of the parents and the state's obligation to protect the child. On the other hand, ethnological research has shown that perceptions of child wellbeing differ considerably between cultures (An-Na'im, I994, p. 62). While we would quickly agree that immersing children in hot baths in order to imbue them with qualities highly prized in other cultures places children in jeopardy, and that the same applies to subjecting children to paininducing initiation rituals, it is equally true that such broadly practised Western customs as

5 See, for example, s. 22 (5)(c); schedule 2, para. II.

6 Art. I200.

7 Art. 274a, Swiss Civil Code.

8 For example, in Switzerland: art. Io7(4), Swiss Civil Code; in Germany: s. I3I4(4), German Civil Code; in France arts. I46 and I8o(I), French Civil Code; and in England and Wales, the Matrimonial Causes Act, ss. I 2 and 13 .

9 Art. 3(I), United Nations Convention on the Rights of the Child. 
making small children sleep in their own beds and their own rooms, or ignoring their hunger pangs so as to induce them to adhere to fixed meal times are met with astonishment and incomprehension by people attuned to African and Asian cultures (Korbin, I98I). Awareness of the cultural dimension to the concept of child welfare is a key prerequisite for effective dialogue between different cultural and legal value systems.

Third, domestic law can integrate Islamic law institutions. This is to say, foreign norms can be translated or transposed if - to simplify somewhat - there are institutions in family law in Europe which are comparable in their function. The most commonly discussed example is the mahr or dower paid by the groom to the bride under Islamic law, which forms an indispensable part of every Islamic marriage (Pearl and Menski, I998, pp. I78-79). The mahr serves to assure the wife a degree of financial independence and to act as a deterrent against arbitrary divorce by repudiation. Given its deep roots in Islamic legal tradition, the mahr is very common among Muslims in Europe as well. This raises the question of how an agreement of this kind would be treated by a European court. In any case, in the context of an Islamic marriage, the mahr constitutes a contractual obligation, and the trust placed in this obligation deserves the protection of the law in the European legal context, too, the details, however, being complex and exacting a case-by-case assessment.

A final step towards incorporating Islamic legal expectations into the context of European law would be to broaden the range of family-law institutions by adding variations based on foreign cultural traditions. Spanish family law, for example, has introduced the option of child guardianship based on the Islamic law concept of kafala. ${ }^{\text {I0 }}$ This institution commits the guardian to protect and look after a child without creating a relationship of filiation as would be the case with adoption, which the Koran forbids (Welchman, 2007, pp. 133-50). English law provides a similar legal institution. The Adoption and Children Act 2002 introduced a new court order, special guardianship, intended to provide another option for legal permanence in addition to adoption. It is open to, among others, carers from minority groups who may wish to offer a child a permanent family and to have parental responsibility, but who have religious or cultural difficulties with adoption as it is set out in law.

One thing which all approaches to cultural diversity based on substantive law have in common is that, unlike approaches rooted in international private law, they avoid abstraction and seek to find common ground and justice in individual cases. They do, however, lay themselves open to criticisms of normative ambiguity and confusion. The resulting overall picture is an eclectic process, a mosaic of cultural considerations which hardly constitutes a systematic view.

\section{Legal pluralism: justification and dangers of a lack of common ground}

Despite all of the possible ways forward, there is evidence that European systems of family law still do not accord sufficient representation to certain interests that are presumed to be cultural. Reports from numerous countries lament the existence of parallel societies, of ethnic and religious enclaves, selfconscious and more or less well-organised communities operating according to their own laws, particularly in matters relating to family law (Pearl and Menski, I998, pp. 77-80; Rude-Antoine, I99I, p. 93). The impression is that migrants from Asia and Africa tend to reconstruct their own legal worlds in the diaspora.

The concept of legal pluralism defines the normative dimensions of pluralistic social structures. It describes the presence and interaction - either harmonious or conflicting - of more than one legal order in the same social field (Griffiths, I986, p. I). Legal pluralism is thus both an analytical framework and the cypher determining the simultaneous fragmentation, pluralisation, 
superposition and fusion of legal systems. It is the result not only of the trans-nationalisation of law and the growth in the number of authorities operating globally and competing with national law, but also of the legal fragmentation which migration is inducing within Western states. Both phenomena are clearly at odds with the legal positivism identifying law with the state, and question many of the core assumptions on which the dominant jurisprudence of the modern nation-state is based.

In the strictly legal conception of legal pluralism, law is only the law made and recognised by the state. This conceptual framework is often criticised as being too narrow and inadequate, the main objection being that it is experientially unsustainable (Shah, 2005, p. 2).

The conception of legal pluralism in cultural anthropology, however, is based on a notion of normative orders which do not imply the authority of the state, but instead evolve in the social planes of human communities (Griffiths, I986, p. I). It takes the view that people's very cultural identity demands that the whole structure of law as an aspect of culture should include all regulations, however apparently different from state law, which specific population groups observe as law in their cultural tradition.

One example is that of the partially autonomous legal culture within the Islamic community in England. Even though persons domiciled in England are subject to English family law, the family lives of many Muslims are in fact determined by unofficial Islamic law, quasi-transplanted through large-scale migration. Couples are wed in the Islamic marriage ceremony of the nikah, and the civil marriage ceremony is regarded as a sort of engagement, which does not in itself allow a marriage to be consummated, although it can be dissolved only by means of a divorce under state law. So Muslim couples marry twice. It is, however, estimated that about one-third of couples marrying under the Islamic nikah ceremony do not become legally married under English law by having a civil marriage ceremony as well (Yilmaz, 2005, pp. 73-74). This number includes many polygamous marriages concluded under the nikah ceremony. The voice of a Muslim woman in England: 'At the end of the day I am a Muslim and for us Muslims a nikah is the most important thing, it is not until you have had the nikah that your marriage is acceptable. I'd be quite happy just to have a nikah, wouldn't go through a civil marriage, there is no need for me to go through that' (Shah-Kazemi, 200 I, p. 33).

A form of legal arbitration, which has been in existence for some twenty years and which is conducted by various Islamic Law Sharia Councils, enjoys substantial jurisdictional authority within the Muslim community and performs functions similar to those performed by a court: advising in matters of family law, assisting in the negotiation of Islamic marriage contracts, and pronouncing Islamic divorces (Bano, 2007, p. 45). The main catalyst driving these religious arbitration authorities has been the fact that Muslim men after a civil divorce at times refused to give an Islamic divorce, to the disadvantage of Muslim women. Civil divorce is regarded by Muslims as a mere formality and often occurs before a religious divorce (Yilmaz, 2003, p. I30). Thus, if a civil divorce is pronounced by an English court and the husband then refuses the talaq, he would then be entitled, under both English law and Islamic law, to enter into a new marriage, because according to English law he is divorced, and according to Islamic law he is still married but entitled to marry a second wife. The wife does not have this right. In the eyes of her community she is still married. Indeed, Islamic divorce is not an entirely unilateral prerogative of the husband. The woman, however, has to apply to a judge (Pearl and Menski, I998, pp. 285-86). Therefore, she must take her case to the Sharia Council and request it to intervene and help dissolve the Islamic marriage (Bano, 2007, p. 48). The same happens when the husband refuses to pay the dower upon divorce. ${ }^{I I}$

I I Since the enactment of the Divorce (Religious Marriages) Act of 2002, English courts can require that a religious dissolution of a marriage must occur before a civil divorce can be pronounced. In other words, an English court can declare that a religious act, to which it ascribes no normative effect whatever, is a prerequisite for its own actions. This Act, however, applies only to Jewish marriages. 
This Islamic family-law order, which in England is both normatively effective yet not officially recognised, preserves not only certain aspects of Islamic law, it also subjects them to new interpretations which are adapted to the social environment concerned. Islamic law is thus reconceptualised, reinterpreted and re-construed (Yilmaz, 2003, p. II8). The result is sometimes also called angrezi sharia, or English sharia (Pearl and Menski, pp. 58-59, 74, 393), a post-modern answer to legal modernity.

The claim of Islamic communities for complete autonomy in family-law matters can be traced back to the I970s and has recently become more assertive and vocal (Poulter, I990, p. I47; I998, pp. 20I-202; Yilmaz, 2005, pp. 59-60). In Britain, Muslims base this claim on the historical fact that in former colonies Muslims were governed by their own religious family law. In India, for example, it was the British Parliament during the days of Empire that gave statutory force to legal pluralism, which involved different religious communities having distinctive systems of personal law (see Tagari, this volume). If this was acceptable for the British in India, Muslims in England see no reason why the co-existence of different family laws should not also be feasible in the UK (Poulter, I990, p. I48). Even the Archbishop of Canterbury has advocated a place for sharia in Britain (2008).

Furthermore, Muslims in England argue that, as members of the Islamic community, they are duty-bound to follow the precepts of sharia in organising their family lives. They view the right to adhere to sharia as an essential part of their religious freedom (Thomson, 2004, p. I).

Were normative systems such as Islamic law to remain unrecognised, the argument is that they would nevertheless continue to operate, albeit unofficially, thus creating tensions and legal uncertainties. So far, the UK government has rejected the introduction of a system of separate personal law for religious communities.

There are good grounds (both dogmatic, and relating to issues of legal theory, legal practice and legal policy) for such post-colonial continuities to be subjected to critical appraisal.

First, it can be argued that both the host nations and the migrant populations of the multicultural societies of twenty-first-century Europe are too multifarious within themselves. A community-based system of personal laws amounts to an unwarranted restriction of plurality. It would replace cultural and religious diversity with a juxtaposition of more or less uniform and closed groups, and would imply that fate has somehow bound the individual to a primordial cultural identity. Moreover, not only Islamic communities, but also the legal precepts they are attached to, vary considerably. There is no body of 'Islamic law'. The Koran is not a legal canon. Rather, the Muslim world incorporates a number of different philosophical traditions, schools of legal thought, and locally specific conventions. There is always a question as to who would decide which particular shade of Islamic family law would be applicable in a particular case. There is certainly a danger that conservative authorities within communities would claim the right to dictate which interpretation was correct. The pitfalls which could arise from inadequate guarantees of due process, of control, independence, transparency, representativeness and democratic legitimacy are real enough. Unlike the decision which the international private law systems of various European countries have made to subject foreign nationals to the family law of their country of nationality, a pluralistic system of personal statutes would effectively mean resorting to classical interpretations of Islamic law. However, in the Arab Islamic countries, these tenth-century interpretations have since seen significant further development. To what extent that further development would be taken into account under a pluralistic system remains unclear (Poulter, I990, p. I58).

Second, pluralistic family-law structures pose a threat to social coherence and cohesion. The uniform rule of law, and the twin principles that the state and only the state has the authority to promulgate law and that the law is equally applicable to all, are essential attributes of the modern state. It follows that a structure of genuine legal pluralism, under which systems of family law would vary from community to community, is both antithetical to the concept of integration and 
indeed even conducive to disintegration - through the furtherance of parallel societies. Clearly, there are differing concepts of nationhood, and individual nations have self-images which are more or less culturally diverse, and these will be either more ethnic or more civic. Nevertheless, in a democratic culture, religious pluralism is dependent on a common understanding of law and a secular legal canon - which has developed from a long and conflict-ridden evolution process - as the foundation of social cohesion. In Refah v. Turkey, the European Court of Human Rights' arguments were essentially that legal pluralism was at odds with secularism, equality and democracy. ${ }^{\text {I2 }}$

Third, these claims are based upon asserting collective or group rights, which in family law raises many conceptual problems, not least of which is that in private law and in international instruments, rights are conceived as individual in nature.

A further problem with asserting group rights is the paradox of multicultural vulnerability, described by Ayelet Shachar (2008, p. 3). This paradox states that the granting of group rights reinforces the structure of order within the family. Authoritarian and oppressive structures within a given social group are thus reinforced rather than dismantled. It is those whose position in a culturally motivated hierarchy is most vulnerable, especially women and children, who bear most of the burden of multicultural accommodation. However, as Kymlicka argues, the aim of minority rights is to provide groups with external protections, rights claimed by a minority group in order to reduce its vulnerability to the economic and political power of the larger society, and not to protect minorities in imposing internal restrictions on their members in the name of tradition and cultural integrity (Kymlicka, I995, p. 34). This argument has merit, since the protection of identity-forming experiences is not an end in itself, but serves the interests of the individual and should permit him or her to decide whether or not to adhere to specific cultural imperatives and religious traditions. We must always recall, however, that in a legally pluralistic system of family law favouring group autonomy, the private sphere of the individual and that of the group are concentric - in the sense that individual rights are subsumed within those of the collective group. The often stated argument that this need not be a major concern provided that there is a right to exit - a right to turn away from cultural imperatives (Reitman, 2005, p. I89) - effectively places the burden of the conflict between group affiliation and personal freedom on the individuals concerned. Often, such individuals will lack the means and opportunities to leave their communities, especially if those communities are repressive.

A final, yet vital objection to group-oriented family law relates to the content of that law. There can be no doubt that many aspects and traditional interpretations of classical Islamic family law are not compatible with the constitutional and human rights enshrined in European countries' legal systems. Equality between the sexes may be a recent achievement, but it is one which is central to European societies' identity. Gender equality extends beyond equivalence of and complementarity between the sexes to include the guarantee of equal access to family-law institutions, even if de facto equality cannot yet be said to have been attained (Büchler 20II, pp. 9I-92). The state's duty to guarantee human rights effectively makes it impossible for key areas of the law to be removed wholesale from the state's authority (see Tagari, this volume).

\section{Beyond cultural and religious identity in family law: discourse and procedure}

Solving the culture or rights conundrum requires an approach combining cultural and individual autonomy in the private sphere. Protecting choice and promoting inclusion (Boyd, 2004) must be

I 2 Refah Partisi (The Welfare Party) and Others v. Turkey, ECHR Grand Chamber, Judgment of I3 February 2003 , Applications nos. 4I340/98, 4I342/98, 4I343/98 and 4I344/98, N I27 and I28. 
the goal, reconciling the protection of cultural identity and autonomy on the one hand with the advancement of social and legal inclusion on the other.

This goal leads us away from thinking based on regulatory policy and institutions towards a view in which discourse and process play the key roles, the insight being that different family-law rationalities all exert their own normative authority (Büchler 20II, pp. 94-96).

The challenge is twofold: on the one hand, an appropriate theoretical framework has to be formulated. On the other hand, various legal institutions in the context of European family-law systems have to be reshaped, both de lege lata, using the legal framework in place, and de lege ferenda.

Thinking about family law in discourses and procedures is to embrace openly the multiplicity of family-law discourses. In contrast to genuinely pluralistic legal structures, what is needed here is a shared compendium of values, a 'we' with the capacity to embrace and be embraced by plurality. Two aspects of a structure within which the different concrete issues arising can be systematically and coherently addressed need to be considered: an external and an internal framework. The outer framework asks about the limits which should be imposed upon the freedom to follow religious and cultural conviction in family affairs. The internal framework addresses the question of which tasks family law has today. Together they frame the answers to the question: To what extent should the family law of European countries allow for the consideration of culturally or religiously informed understanding and beliefs?

A growing number of international conventions show an increasing convergence in values, and these conventions provide the external framework for family-cultural autonomy and plurality. Examples are the European Convention on Human Rights, the Convention on the Elimination of All Forms of Discrimination against Women and the United Nations Convention on the Rights of the Child. It is they that clothe in words the irreducible, core convictions which unite societies and are thus not negotiable. Inviolability of the person and equality between the sexes are among them. Important is the understanding that human rights can meaningfully and productively be connected with different traditions.

The internal framework of autonomy in family law has to focus on the question of which tasks family law has today, given the multiplicity of ways people conduct their family lives.

Family law must protect a form of personal autonomy, which may include the right and capacity to contract. Contractual autonomy is at the core of private law in liberal societies and plays a key role also in family law. We are witnessing the deinstitutionalisation and contractualisation of family law in recent decades. Two interwoven aspects of this process are worth noting. First, constructionist accounts of family law have unveiled and questioned how traditional legal discourse privileges certain family forms and individual behaviour. In recent decades the concept of the family has been broadened, focusing less on the institution of marriage and more on the function of a family unit and the tasks different people fulfil. Second, family law now ascribes greater importance to negotiated, self-determined solutions, accords sovereignty in interpretation to the parties, and concerns itself with the procedural aspects namely of separation. The integration of Islamic perceptions of family law in the manner envisaged here is part of the deinstitutionalisation and contractualisation of family law (Büchler 20II, p. I04).

A purely contractual view may overlook hierarchical patterns, dependency and inequality in relationships. The juxtaposition with a substantial argument and a justice requirement in contracting is needed. When reduced to its protective role, family law in the economic arena should ensure that the principles of private law which go along with the autonomy of the parties are also respected within the intimacy of a couple, and its tasks here include ensuring equitable compensation for contributions to family life, equitable sharing of its burdens and that legitimate expectations that have been created by the relationship between partners may be met. The institution of marriage, however, would not play the key role any longer. 
In the personal sphere, care must be taken of the children, their integrity should be defended, their rights ensured and their network of relationships protected - independently of the status of their parents (Büchler 20II, pp. I05-I06).

The true core of family law, however, is increasingly seen as supporting the parties and assisting them in using the freedom of action they enjoy responsibly and creatively. While it should not be the family law's main purpose to determine legal outcomes, and its sway over such outcomes should only be marginal, the legal process should nevertheless be organised, accompanied and safeguarded.

Numerous projects and legal practices in place in various countries are testimony to the growing use of procedural and deliberative approaches in family law and can be developed further.

An example of the extensive procedural integration of foreign law can be seen in the efforts that have been made in Canada to institutionalise arbitration courts which draw on sharia as a transnational legal source and method of legal decision-making (Boyd, 2004, p. I33). The idea was to allow the parties to resolve certain family-law disputes outside the traditional court system. Various protective mechanisms would have allowed the court to rescind arbitration decisions which do not protect the child's wellbeing or where one of the parties has had no access to independent legal advice (Boyd, 2004, pp. I09-I32). Although exhaustive scientific and legal policy discussions ultimately resulted in arbitration decisions based on the application of religious law being declared non-binding, the potential that arrangements of this kind would have in European countries has yet to be fully investigated.

A less far-reaching approach can be seen in efforts to use incorporation and interaction to fashion open procedures to accommodate cultural dimensions. Such efforts avoid relinquishing the state's prerogatives for legislation and the application of the law, attempting instead to make family-law institutions more inclusive in their effect. Cultural practices can be drawn into the law in a variety of ways here, including relaxing the form requirements for marriage ${ }^{\mathrm{I} 3}$ or divorce, ${ }^{\mathrm{I} 4}$ and taking culture into account in determining the needs and best interests of children (see Brophy, Jhutti-Johal and Owen, 2003).

The advantages of family-law thinking based on discourse and procedure are that it does not accept an existentialised concept of culture or the manipulative abuse of contextual specificity or cultural relativity, and avoids clothing social conflicts in primordial arguments. By co-ordinating discourse and moderating conflicts, it is thus better placed to grasp the differentiations, dynamic interactions and diversity of perspectives within a society.

Further, the incorporation of some awareness of Islamic family-law tradition into court procedures is very much of a piece with the evolution towards a more contractual and less institutional nature of family law seen in recent decades in Europe. The increasing plurality of modes of living means that narrowly prescriptive family-law models require particular justification. The law, however, should keep taking its cue not from the interests of the group, but rather from those of the individual. In this way, law and legal practice uphold diversity in family arrangements whether or not they are reflective of differences in culture or religion. An approach that focuses on individual positions rather than on group interests, on the one hand focuses on the shared meanings while on the other hand it is able to grasp differences in positions and

I3 Spain, for example, has introduced the option of Islamic marriage with compulsory state registration; art. 59, Spanish Civil Code.

I4 For example, while it is true that the Islamic talaq marriage dissolution, in its classical form, contravenes the principles of equality between the sexes and of human dignity, this would not be the case if the wife were granted the right to a hearing and agreed to the divorce on the basis of mutual consent. Indeed, there are cases in which the wife has been granted a delegated talaq, where it is she who pronounces the divorce (Pearl and Menski, I998, p. 283). Another example might be to incorporate into existing alternative dispute resolution mechanisms Islamic reconciliation and arbitration procedures which often call upon the couple's relatives to negotiate the consequences of a divorce (Bano, 2007, pp. 54-55). 
interests within groups, different self-conceptions, self-images and legal understandings. A search for a true interpretation of Islamic legal institutions is thus not necessary.

The discursive, procedure-based approach to questions of family law protects the selfinterpretation of cultural imperatives. For autonomy to be substantive, however, it must enable the individual to choose between various options without coercion. There are a number of prerequisites for this, not the least of which are institutional and procedural guarantees (Büchler 20II, p. II8).

Finally, even within a discursive, procedure-based approach, there remains the problem of structural and familial inequality of the sexes. The discourse of accommodation of cultural and religious identity in family law focuses on the question of violation of gender equality through religious law, often suggesting a binary opposition between culture and religion on the one hand and human rights and gender equality on the other, and thereby positing culture and women's rights as in competition and viewing human rights values and gender equality as external to culture (Mehra, 2007).

There are many problems with thinking in these binary terms. First, the focus on cultural practices affecting migrant women implies a 'gendered dimension of the culture clash hypothesis' (Powell, 2005, p. 334), at the same time diverting attention away from gender discrimination closer to home. The rhetoric is all too often one that suggests non-Western family law and practices are 'cultural', whereas European ones are 'rational'. Culture is in general invoked selectively and only in relation to characteristics and behaviour of minorities (Volpp, 200I, p. II85). This view overlooks the specific manner in which gender structures social relations and in which a specific practice enforces power relations.

Second, a discursive strategy suggesting a binary opposition between culture or religion and gender equality essentialises the notions of culture and gender and ties gender roles to a specific cultural context. Women, therefore, are left with the choice of cultural belonging or gender equality rights (Büchler 20II, p. II9).

Third, the discourse victimises women belonging to a foreign culture, denying their potential to be understood as emancipatory subjects and their agency (Volpp, 200I, p. I205). It assumes that 'other' women passively wait to be rescued from cultural dictates.

Finally, it also undermines the work of women in the Islamic context and misrepresents many members of the community that do not share and would never support the cultural understanding of certain practices. Women, however, can and do challenge the validity of cultural claims and provide alternative interpretations to the mainstream, male-dominated reading of religious and other texts. A similar struggle took place in Europe, too, when women fought an interpretation of equality that excluded women.

Nevertheless, since Foucault, no discourse can elude the power structure which defines that very discourse itself. Empirical social studies show that while women living in Islamic communities in Europe do not wish to relinquish their ultimate right of resorting to state law, their individual and collective identities are closely interwoven, and individual identity can be stabilised only in the context of the social network. Women from an Islamic country living in Europe acknowledge and stress the heterogeneity of law in their everyday lives. They recognise, negotiate and contest different cultural identities and legal practices (Shah-Kazemi, 200I, pp. 70-7I).

A familiar discursive environment, encompassing people living in the same cultural context, favours the disclosure of interests involved, thus making it harder to retreat to purely culturalised attitudes. Such an approach fosters a sense of cultural security, which in turn strengthens individual autonomy.

We are confronted with the elusive nation. The discourse on legal pluralism challenges the notion of state law as the only and privileged source of law and offers conceptions of law beyond the state. The nation-state, however, still has its function, particularly in the legal world, and its 
foremost task is to secure democratic legitimacy and an adjudicative structure. To find a place for family law that is beyond culture and religion, we must focus on its core tasks and ensure it is void of religiously informed content. To think family law beyond culture means to dismiss the necessity or even the potential to preserve cultural identities as established and delineable entities and to accept the internal complexity and essential contestability of cultures (Benhabib, 2002, p. ix). Thus, family law beyond culture is most likely to accommodate the general hybridisation of cultural legacies, the blurring and shifting of unbounded cultural beliefs. Family law itself then loses its cultural and moral imprint and in its restatement focuses on the primary tasks of private law in general. Finally, in everyday practice, debate in this area needs to be less abstract and ideological, and more detailed, concrete and context-related.

\section{References}

AN-NA'Im, Abdullahi (I994) 'Cultural Transformation and Normative Consensus on the Best Interests of the Child', International Journal of Law and the Family 8(I): 62-8I.

ARCHBISHOP OF CANTERBURY, Dr Rowan Williams (2008) 'Civil and Religious Law in England: A Religious

Perspective', Lecture, Royal Courts of Justice. Available at: www.archbishopofcanterbury.org/ articles.php/ I I 37/archbishops-lecture-civil-and-religious-law-in-england-a-religious-perspective

(last accessed I4 February 20I2).

BAINHAM, Andrew (I995) 'Family Law in a Pluralistic Society', Journal of Law and Society 22(2): 234-47. Bano, Samia (2007) 'Muslim Family Justice and Human Rights, the Experience of British Muslim

Women', Journal of Comparative Law I(4): 38-67.

Benhabib, Seyla (2002) The Claims of Culture: Equality and Diversity in the Global Era. Princeton: Princeton University Press.

BOYD, Marion (2004) Dispute Resolution in Family Law: Protecting Choice, Promoting Inclusion. Available at: www.attorneygeneral.jus.gov.on.ca/english/about/pubs/boyd/fullreport.pdf (accessed I I January 2010).

вrophy, Julia, Jhutti-johal, Jagbir and owen, Charlie (2003) Significant Harm: Child Protection in a Multicultural Setting. London: Lord Chancellor's Department.

BüCHLER, Andrea (20I I) Islamic Law in Europe? Legal Pluralism and its Limits in European Family Laws. Farnham/Burlington: Ashgate.

FoblETs, Marie-Claire (2000) 'Migrant Women Caught Between Islamic Family Law and Women's Rights: The Search for the Appropriate "Connecting Factor", Maastricht Journal of European and Comparative Law 7(I): I I-35.

Fux, Beat (2002) 'Which Models of the Family Are Encouraged or Discouraged by Different Family Policies?', in Franz-Xaver Kaufmann, Anton Kujisten, Hans-Joachim Schulze and Klaus Peter Strohmeier (eds), Family Life and Family Policies in Europe. Vol. 2: Problems and Issues in Comparative Perspective. Oxford: Oxford University Press, 363-4I8.

GRIFFITHS, John (I986) 'What is Legal Pluralism?', Journal of Legal Pluralism 24(I): I-55.

Kaufmann, Franz-Xaver (2002) 'Politics and Policies Towards the Family in Europe: A Framework and an Inquiry into Their Differences and Convergences', in Franz-Xaver Kaufmann, Anton Kujisten, Hans-Joachim Schulze and Klaus Peter Strohmeier (eds), Family Life and Family Policies in Europe. Vol. 2: Problems and Issues in Comparative Perspective. Oxford: Oxford University Press, 4I9-90. Korbin, Juliet (I98I) Child Abuse and Neglect: Cross-Cultural Perspectives. Berkeley: University of California Press.

KRAUSE, Harry (2006) ‘Comparative Family Law: Past Traditions Battle Future Trends - and Vice Versa', in Mathias Reimann and Reinhard Zimmermann (eds), The Oxford Handbook of Comparative Law. Oxford: Oxford University Press, I099-I I30. 
кymLicka, Will (1995) Multicultural Citizenship: A Liberal Theory of Minority Rights. Oxford: Oxford University Press.

MeHra, Madhu (2007) 'Women's Equality and Culture in the Context of Identity Politics', Journal of Comparative Law 2(2): 6-37.

nachmani, Amikam (2009) Europe and its Muslim Minorities: Aspects of Conflict, Attempts at Accord.

Brighton: Sussex Academic Press.

PEARL, David and MENSKI, Werner (I998) Muslim Family Law, 3rd edn. London: Sweet \& Maxwell.

Poulter, Sebastian (I990) 'The Claim to a Separate Islamic System of Personal Law for British

Muslims', in Chibli Mallat and Jane Connors (eds), Islamic Family Law. London/Dordrecht/

Boston: Graham \& Trotman, I47-66.

Poulter, Sebastian (1998) Ethnicity, Law and Human Rights: The English Experience. Oxford: Oxford

University Press.

POWELL, Catherine (2005) 'Lifting Our Veil of Ignorance: Culture, Constitutionalism, and Women's

Human Rights in Post-September I I America', Hastings Law Journal 57: 33 I-72.

Reitman, Oonagh (2005) 'On Exit', in Avigail Eisenberg and Jeff Spinner-Halev (eds), Minorities within

Minorities: Equality, Rights and Diversity. Cambridge: Cambridge University Press, 189-208.

ROHE, Mathias (2004) 'The Application of Islamic Family Law in German Courts and its Compatibility

with German Public Policy', in Jürgen Basedow and Nadjma Yassari (eds), Iranian Family and Succession Laws and their Application in German Courts. Tübingen: Mohr Siebeck, I9-34.

RUde-Antoine, Edwige (I 99I) 'Muslim Magrebian Marriage in France: A Problem for Legal Pluralism', International Journal of Law and the Family 5(2): 93-103.

shachar, A. (2008) Multicultural Jurisdictions: Cultural Differences and Women's Rights. Cambridge:

Cambridge University Press.

SHAH, Prakash (2005) Legal Pluralism in Conflict: Coping with Cultural Diversity in Law. London:

Routledge Cavendish.

SHAH-KAZEMI, Sonia Nurin (200I) Untying the Knot: Muslim Women, Divorce and the Shariah. London:

Nuffield Foundation.

THomson, Ahmad (2004) 'Incorporating Muslim Personal Law into UK Domestic Law'. AMSS (UK) 5th

Annual Conference - Fiqh Today, Sunday 22 February 2004. Available at: www.wynnechambers.

co.uk/pdf/AMSS-ATNotes2 20204.pdf (accessed I I January 20I0).

VAN DER VEER, Peter (1994) Religious Nationalism, Hindus and Muslims in India. Berkeley: University of

California Press.

volpp, Leti (200I) ‘Feminism Versus Multiculturalism’, Columbia Law Review Ior(5): I I I I-2 I8.

welchman, Lynn (2007) Women and Muslim Family Laws in Arab States: A Comparative Overview of Textual Development and Advocacy. Amsterdam: Amsterdam University Press.

YILMAZ, Ihsan (2003) 'Muslim Alternative Dispute Resolution and Neo-Ijtihad in England', Alternatives, Turkish Journal of International Relations 2(I): I I7-39.

YILMAz, Ihsan (2005) Muslim Laws, Politics and Society in Modern Nation States: Dynamic Legal Pluralisms in England, Turkey and Pakistan. London: Ashgate. 